\title{
Forensic case of a pregnant woman with Marfan syndrome
}

\author{
Isabella Aquila (10 , Matteo Antonio Sacco, Fabrizio Cordasco, Pietrantonio Ricci
}

University Magna Graecia of Catanzaro, Institute of Legale Medicine, Catanzaro, Italy

\section{Correspondence to}

Dr Isabella Aquila;

isabella.aquila@hotmail.it

Accepted 26 November 2020

\section{DESCRIPTION}

Marfan syndrome is an autosomal dominant disorder associated with changes in the FBN1 gene and is one of a group of disorders where changes in genes encoding proteins essential for elastic fibres alter tissue elasticity and friability. ${ }^{1}$ This genetic disease is characterised by various presentations and great clinical variability and therefore difficulties in the diagnosis. ${ }^{2}$ We present the case of a young woman at the ninth month of pregnancy. She was unaware of the disease. She was admitted to the hospital to give birth and she died 2 days after a caesarean section. After the surgery, the woman complained of pain in the shoulders; the physicians performed an echocardiogram that showed aortic dilation $(40 \mathrm{~mm})$ with no haemopericardium. A pulmonary V/ Q scan (scintigraphy) was also performed, which suggested a left pulmonary embolism.

After her death, an autopsy was carried out to understand the cause of death. In the case reported, postmortem investigations showed external anatomical features and internal signs that led to

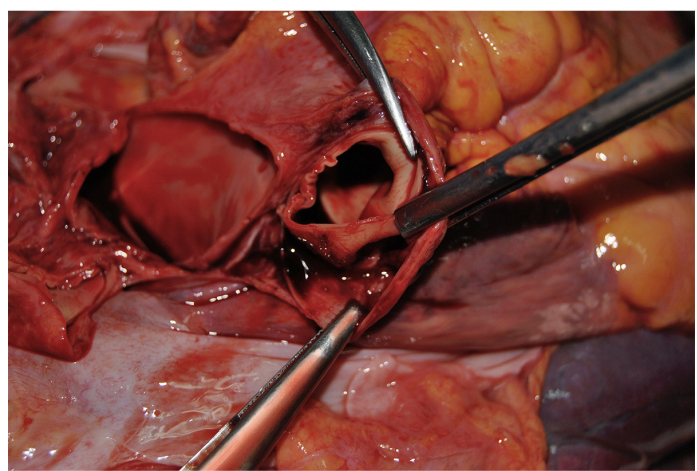

Figure 1 Type A aorta dissection with the generation of a false lumen.

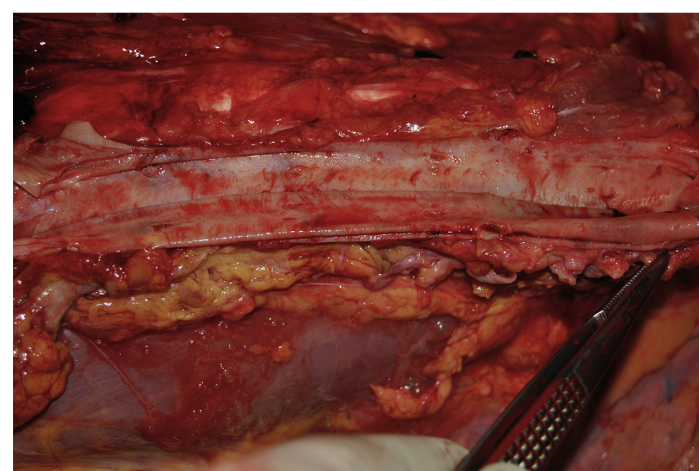

Figure 2 Particular of aorta dissection.

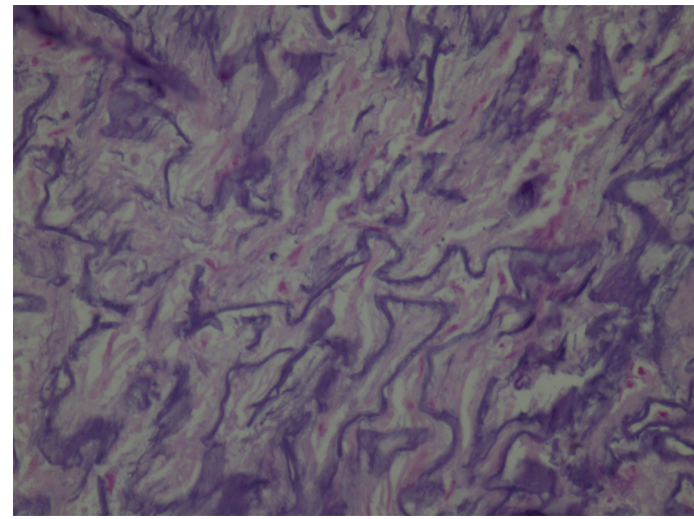

Figure 3 Fragmentation of elastic fibres at histological examination of the aorta with $\mathrm{H} \& \mathrm{E}$.

the suspicion of Marfan Syndrome (MS). This disease along with other factors, such as obesity, and hormonal changes that occur during pregnancy, especially the increase in oestrogens levels, can cause a greater likelihood of development of aortic dissection during pregnancy. Therefore, it is essential to make a proper diagnosis of this clinical condition. ${ }^{3}$ Patients, who do not know they are affected by this clinical condition, do not take appropriate lifestyle or medical precautions. When

Learning points

- The diagnosis of Marfan syndrome is sometimes difficult due to the variability of the clinical presentation. In the case reported, careful observation of clinical signs, analysis of the clinical and family history, supported by genetic investigation performed on biological fluids and the histological study of the vessels involved, provided the postmortem diagnosis. We emphasise the importance of taking appropriate samples at postmortem to facilitate genetic testing and diagnosis.

- Early detection in individuals with a habitus suggestive of Marfan syndrome is essential to avoid fatal complications during pregnancy, especially in women who have other risk factors, such as obesity. The physiologically elevated oestrogen levels during pregnancy are likely to contribute to the risk of aortic rupture.

- Accurate diagnosis is also important for the genetic evaluation and prevention of disease in other family members. Appropriate medical follow-up and prophylactic therapy may prevent morbidity and mortality in relatives. 
we evaluated the family and medical history, it was revealed that her father had died suddenly at the age of 40 . The circumstances of his death were compatible with aortic rupture. The woman's external examination, $178 \mathrm{~cm}$ tall and weighing $139 \mathrm{~kg}$, showed the presence of arachnodactyly with the incidental lack of a phalanx of the right hand and particularly long legs in connection with overall height. Autopsy revealed a type A dissection according to the Stanford classification, with the generation of a false lumen (figures 1 and 2). However, there was not an aortic wall rupture, and therefore, there was no free blood in the chest or pericardium. Histological examination of the aorta showed pseudocystic degeneration with mucosal deposition, artery dissection, disorientation and fragmentation of the elastic fibres (figure 3). These results suggest a possible diagnosis of Marfan syndrome. Autopsy results revealed that the causes of death were aortic dissection, caused by Marfan syndrome, and pulmonary embolism. The diagnosis of Marfan was confirmed by genetic testing. A variant in FBN1 was detected. Genetic analysis revealed a single base deletion in exon $39 .{ }^{4}$
Contributors IA performed autopsy with PR. FC performed the revisions and MAS performed the review of literature and wrote the paper with IA.

Funding The authors have not declared a specific grant for this research from any funding agency in the public, commercial or not-for-profit sectors.

Competing interests None declared.

Patient consent for publication Not required.

Provenance and peer review Not commissioned; externally peer reviewed.

\section{ORCID iD}

Isabella Aquila http://orcid.org/0000-0002-2481-6050

\section{REFERENCES}

1 Gutman G, Baris HN, Hirsch R, et al. Loeys-Dietz syndrome in pregnancy: a case description and report of a novel mutation. Fetal Diagn Ther 2009:26:35-7.

2 Dean JCS. Marfan syndrome: clinical diagnosis and management. Eur J Hum Genet 2007; 15:724-33.

3 Aquila I, Sacco MA, Gratteri S, et al. Sudden death by rupture of a varicose vein: case report and review of literature. Med Leg J 2017:85:47-50.

4 El-Aleem AA, Karck M, Haverich A, et al. Identification of 9 novel FBN1 mutations in German patients with Marfan syndrome. Hum Mutat 1999;14:181.

Copyright 2020 BMJ Publishing Group. All rights reserved. For permission to reuse any of this content visit https://www.bmj.com/company/products-services/rights-and-licensing/permissions/

BMJ Case Report Fellows may re-use this article for personal use and teaching without any further permission.

Become a Fellow of BMJ Case Reports today and you can:

- Submit as many cases as you like

- Enjoy fast sympathetic peer review and rapid publication of accepted articles

- Access all the published articles

- Re-use any of the published material for personal use and teaching without further permission

\section{Customer Service}

If you have any further queries about your subscription, please contact our customer services team on +44 (0) 2071111105 or via email at support@bmj.com.

Visit casereports.bmj.com for more articles like this and to become a Fellow 